\title{
THE EFFECT OF FINDING DECISION, PROFITABILITYAND DIVIDEND POLICY TO FIRM VALUE OF CONSUMER GOODS INDUSTRY AT INDONESIA STOCK EXCHANGE IN THE PERIOD OF 2012-2016
}

\author{
Dwi Nur Sahid $^{1}$, Lies Zulfiati ${ }^{2}$ \\ PT Buyung Poetra Sembada Tbk ${ }^{1}$ \\ Ps. Induk Cipinang Blk. K No.17, RT.3/RW.12, Cipinang - Jakarta, Indonesia \\ Sekolah Tinggi Ilmu Ekonomi Indonesia ${ }^{2}$ \\ J. Kayu Jati Raya No. 11A, Rawamangun - Jakarta, Indonesia \\ soetjiatinayla@gmail.com ${ }^{1}$, rimigusliana@gmail.com²
}

\begin{abstract}
The purpose of this research is to determine whether the Funding Decision, Profitability Ratio, and Dividend Policy both individually and simultaneously affect significantly the firm value of the consumer goods industry in the Indonesia Stock Exchange (BEI) period 2012-2016.Funding Decision is represented by using Debt to Equity Ratio (DER), Profitability is represented by using Return On Equity (ROE), Dividend Policy is represented by using Devidend PayOut Ratio (DPR). By using purposive sampling technique, the sample used in this study amounted to 100 companies from the population of 20 companies and the period of research are 5 years. This causal-comparative research uses panel data with secondary data that collected by using documenting and archiving techniques from Indonesian Capital Market Electronic Library. Multiple regression estimation method from panel data used in this research is Fixed Effect Model. This research shows that Funding Decision (regression coefficient 5,419856), Profitability (regression coefficient -11,14584), and Devidend Policy (regression coefficient 0,468592 ) individually and silmutaneously affect the stock return of the consumer goods industry sector in the period of 2012-2016 significantly, with the value of Adjusted $R^{2}$ is 0,940623 .
\end{abstract}

Keyword : Funding Decision, Profitabilty,Devidend Polic, Firm Value, Debt-to-Equity Ratio, Return On Equity, Devidend payout Ratio, Price Book Value Fixed Effect Model. 


\section{PENDAHULUAN}

Di era modern ini banyak terdapat perusahaan yang bergerak diberbagai macam sektor yang bersaing sangat ketat. Pada dasarnya setiap perusahaan yang didirikan bertujuan untuk mendapatkan laba, dan tentunya perusahaan menginginkan laba yang terus meningkat dari waktu ke waktu. Untuk itu perusahaan perlu menjamin nilai perusahaannya tumbuh secara berkelanjutan. Saat ini informasi keuangan yang hanya dalam bentuk laba saja tidak cukup untuk menjamin keberlanjutan perusahaan. Perusahaan perlu memberikan informasi lain yang dibutuhkan oleh stakeholder dalam hal pengambilan keputusan (Hastuti dan Rachbini, 2014).

Salah satu rasio yang banyak digunakan dalam mengambil keputusan investasi adalah rasio harga saham terhadap nilai buku perusahaan (price book value). Nilai buku perusahaan adalah nilai aset perusahaan dibagi jumlah saham yang diterbitkan perusahaan, dengan kata lain, nilai buku saham merupakan nilaiwajar dari saham emiten tersebut, sementara harga saham bisa dipengaruhi oleh banyak faktor.Harga saham yang ada di bursa efek selalu mencerminkan perkiraan kinerja atau nilai buku perusahaan di masa depan, karena pada dasarnya orang yang membeli saham adalah membeli masa depan, untuk berinvestasi dalam jangka waktu panjang (Afzal dan Rohman, 2012).

Menurut Sugihen (2012) menyatakan bahwa indikator price book value (PBV) digunakan untuk menunjukkan seberapa jauh suatu perusahaan mampu menciptakan nilai perusahaan relatif terhadap jumlah modal yang diinvestasikan, semakin tinggi rasio tersebut semakin berhasil perusahaan menciptakan nilai bagi pemegang saham, dengan mengetahui rasio PBV, investor bisa mengidentifikasi saham mana yang harganya wajar, undervalued, dan overvalued. Penggunaan PBV sebagai proksi yang mewakilkan nilai perusahaan juga digunakan pada sebagian besar penelitian yang menggunakan nilai perusahaan dalam variabel penelitiannya. Nilai perusahaan merupakan ukuran keberhasilan atas pelaksanaan fungsi-fungsi keuangan. Nilai perusahaan dapat diartikan sebagai ekspektasi nilai investasi pemegang saham (harga pasar ekuitas) dan atau ekspektasi nilai total perusahaan (harga pasar ekuitas ditambah dengan nilai pasar utang, atau ekspektasi harga pasar aset.

Babu dan Jain (2012) menyatakan empat alasan mengapa perusahaan lebih menyukai menggunakan utang daripada saham baru, yaitu (1) Adanya manfaat pajak atas pembayaran bunga; (2) Biaya transaksi pengeluaran utang lebih murahdaripada 
biaya transaksi emisi saham baru; (3) Lebih mudah mendapatkan pendanaan utang daripada pendanaan saham; (4) Kontrol manajemen lebih besar adanya utang baru daripada saham baru. Penerbitan utang merupakan sinyal adanya good news yaitu manajer lebih yakin atas kinerja perusahaan pada masa mendatang sehingga harga saham meningkat dengan adanya pengumuman kenaikan utang, harga saham yang meningkat mencerminkan peningkatan nilai perusahaan. Pemaparan di atas memberikan kesan bahwa bagi setiap perusahaan, keputusan dalam pemilihan sumber dana merupakan hal penting sebab hal tersebut akan mempengaruhi struktur modal perusahaan, yang akhirnya akan mempengaruhi kinerja perusahaan. Sumber dana perusahaan dicerminkan oleh modal dari luar dan modal sendiri yang diukur dengan debt to equity ratio (DER).Jika DER semakin tinggi, maka nilai perusahaan akan meningkat selama DER belum sampai pada titik optimalnya sesuai dengan trade-off theory. Trade-off theory juga menyatakan bahwa dengan meningkatnya nilai DER (jumlah utang yang semakin besar) dapat meningkatkan profitabilitas, hanya jika utang yang bertambah jumlahnya digunakan secara benar.

Dividen seringkali digunakan sebagai indikator atau sinyal prospek suatu perusahaan. Pramastuti (2012) dalam penelitiannya mengenai pengaruh pengumuman kebijakan dividen menyimpulkan bahwa kenaikan (penurunan) dividen direspon secara positif (negatif) oleh pasar. Perusahaan dengan pertumbuhan yang tinggi, seringkali tidak membagikan dividen. Mereka mengunakan uang yang merupakan dividen shareholders untuk mendanai pertumbuhan perusahaan yang tinggi tersebut.

\section{Gambar 1}

\section{Kinerja Sektor Barang Konsumsi Tahun 2015}

\begin{tabular}{|lcc|} 
& Weekly (\%) & 2015 YTD Performances \\
Composite & 1 & $-4.92 \%$ \\
Agri & -3.52 & $-12.69 \%$ \\
Mining & -1.08 & $-16.42 \%$ \\
Basic Ind & 0.54 & $-19.33 \%$ \\
Misc-Ind & -0.48 & $-6.50 \%$ \\
\hline Consumer & 0.98 & $1.11 \%$ \\
\hline Property & 1.39 & $-5.47 \%$ \\
Infra & 0.82 & $-9.58 \%$ \\
Finance & 2.65 & $-2.12 \%$ \\
Trade & 0.57 & $4.55 \%$ \\
\hline JCI PE R $(x)$ & & 13.09 \\
JCI PBV $(x)$ & & 2.08 \\
\hline
\end{tabular}

*)Sumber www.tradingeconomic.com

Pada Gambar 1 terlihat jelas return (imbal hasil) saham sektor barang konsumsi di pasar modal Indonesia. sektor barang konsumsi masih dapat bertumbuh positif 
sebesar 1.11\% (year-to-date) di lihat dari kinerja sektor barang konsumsi, jika dibandingkan dengan IHSG sebagai aktor utama. Untuk mendapatkan saham-saham yang berkualitas dibutuhkan skill yang cukup tinggi, hasil pengamatan yang jeli baik dari sisi keuangan maupun perubahan industri itu sendiri.

Dalam pembahasan kali ini, peneliti hanya akan menggunakan rasio yang cukup umum dan banyak dikenal oleh praktisi dan masyarakat, yakni operating profit (rasio profitabilitas), yang merupakan rasio yang bertujuan untuk mengetahui kemampuan perusahaan dalam menghasilkan laba selama periode tertentu dan juga memberikan gambaran tentang tingkat efektifitas manajemen dalam melaksanakan kegiatan operasionalnya, untuk kasus disini peneliti lebih menyukai penggunaan operating profit setelah menghitung hasil dari kinerja operasionalnya yang berdasarkan beban umum dan administrasi (seperti diketahui, umumnya sektor konsumsi semisal unilever menggunakan biaya yang cukup besar pada pos marketing expense).

Dari total 30 lebih perusahaan yang tergabung pada sektor barang konsumsi, hanya terdapat 6 perusahaan yang memiliki pertumbuhan OPM (Operating Profit Margin) di atas $20 \%$, di sisi lain peneliti juga memasukan pertumbuhan perusahaan berdasarkan laba bersih yang meningkat di atas 20\% selama 3(tiga) tahun terakhir dan mendapatkan sedikitnya 7 (tujuh) perusahaan yang mampu bertumbuh di atas $20 \%$ dalam 3(tiga) tahun terakhir.

\begin{tabular}{|lc|lc|}
\hline & \multicolumn{3}{c}{ Gambar 2 } \\
Hasil Operating Profit Margin \\
\hline \\
OPM (TTM) \% & & $\begin{array}{c}\text { Net Income } \\
\text { (Growth: } 3 \text { year) }\end{array}$ \\
\hline ADES & 43.88 & KICI & 136.24 \\
DLTA & 37.75 & STTP & 42.5 \\
MERK & 21.98 & ULTJ & 42.25 \\
MLBI & 31.39 & SKLT & 41.58 \\
SIDO & 20.29 & AISA & 37.76 \\
UNVR & 22.7 & ADES & 26.21 \\
DLTA & 24.82 \\
\hline
\end{tabular}

*)Sumber www.tradingeconomic.com

Dari gambar 2 dapat di lihat saham seperti ADES, DLTA, dalam pengamatan kami memiliki hasil laba bersih dan operating profit yang cukup tinggi dan stabil, hal ini dikarenakan perusahaan bergerak di bisnis yang tidak terlalu banyak pesaingnya, ADES (memproduksi air mineral dan minuman ringan) - pesaing utama tentu AQUA, serta DLTA.

Namun jika ingin berinvestasi di pasar modal peneliti sarankan tidak terlalu berharap yang lebih, karena saham DLTA saat ini tidak likuid dan memiliki volume 
yang tidak likuid di pasar. Memang tetap yang terbaik dari sektor ini adalah saham unilever (UNVR), stabil dalam membagikan dividen serta cukup kuat dalam penetrasi bisnis di pasar, serta memilki kinerja OPM yang cukup baik di atas $20 \%$. Secara valuasi saham UNVR memang memiliki PE di atas 50x (premium), jika anda memang ingin berinvestasi dalam jangka panjang saya sarankan bisa memilih saham ULTJ (PE 32x) dan INDF (PE 17.78x), ULTJ sendiri memiliki pertumbuhan laba bersih yang cukup stabil dan di atas 35\% dalam 3 tahun terakhir. Mengingat memang sektor barang konsumsi yang cukup defensive (dividen + capital gain) secara langsung memang cukup berpengaruh dengan valuasi sektoral yang memasuki area premium.

Berdasarkan latar belakang masalah dalam penelitian ini maka rumusan masalah dalam penelitian ini adalah untuk mengetahui apakah keputusan pendanaan, profitabilitas dan kebijakan deviden secara individual dan bersama-sama berpengaruh terhadap nilai perusahaan emiten sektor industri barang konsumsi di Bursa Efek Indonesia periode 2012-2016. Sedangkan tujuan yang ingin dicapai adalah untuk mengetahui dan memperoleh bukti empiris pengaruh pengaruh keputusan pendanaan, profitabilitas dan kebijakan deviden terhadap nilai perusahaan pada perusahaanperusahaan sektor industri barang konsumsi yang terdaftar di Bursa Efek Indonesia periode 2012-2016.

\section{KAJIAN TEORI}

Nilai Perusahaan. Nilai perusahaan dapat didefinisikan sesuai tujuan yang berbeda-beda. Nilai likuiditasi (liquidating value) merupakan nilai aktual per lembar saham yang akan diterima apabila seluruh asset perusahaan dijual sesuai harga pasar, seluruh kewajiban dibayar dan kelebihannya dibagikan kepada pemegang saham (Gitman, 2012:352). Menurut Sartono (2012:487), nilai Perusahaan adalah nilai jual sebuah perusahaan sebagai suatu bisnis yang sedang beroperasi. Adanya kelebihan nilai jual diatas nilai likuidasi adalah nilai dari organisasi manajemen yang menjalankan perusahaan itu.

Metode Perhitungan untuk menentukan nilai perusahaan adalah sebagai berikut :

$$
\text { Price Book Value }=\frac{\text { Harga pasar per lembar saham }}{\text { Nilai buku per lembar saham }}
$$


Keputusan Pendanaan. Keputusan pendanaan sering disebut juga sebagai kebijakan capital structure atau struktur modal. Dalam hal ini, manajer keuangan dituntut untuk memperoleh dana yang ekonomis yang akan dibelanjakan untuk usaha usaha perusahaan dan investasinya. Dalam memperoleh sumber dana, tentu saja manajer keuangan juga dituntut untuk menganalisis dan mengkombinasikannya dari sumber sumber dana yang ekonomis tersebut. Ada pun sumber dana tersebut dapat diperoleh dari internal perusahaan (laba ditahan), sedangkan dana dari eksternal dapat diperoleh dari menerbitkan saham baru, menerbitkan/menjual obligasi, dan memperoleh pinjaman dari bank.

Keputusan pendanaan berkaitan dengan keputusan mencari sumber dana yang paling menguntungkan. Idealnya dana yang diperoleh organisasi mempunyai biaya yang paling kecil, tetapi biasanya ada trade-off antara biayamurah (yang berarti keuntungan) dengan risiko. Sebagai contoh, utang merupakan sember dana yang murah karena tingkat bunga efektif merupakan tingkat bunga nominal dikurangi penghematan pajak. Tetapi semakin tinggi utang, semakin berkurang fleksibilitas perusahaan.

Hanafi (2015:12) menyatakan bahwa keputusan pendanaan bervariasi mulai dari pendanaan jangka pendek, seperti utang bank jangka pendek atau utang dagang, sampai utang jangka panjang seperti utang jangka, menerbitkan obligasi atau menerbitkan saham.

Debt Equity Ratio, Ratio ini menunjukkan hubungan antara jumlah utang yang diberikan oleh para kreditur dengan jumlah modal sendiri yang diberikan oleh pemilik perusahaan (Horne, 2013:140). Debt to Equty Ratio dapat dihitung sebagai berikut:

$$
\text { Debt Equity Ratio }=\frac{\text { Total Hutang }}{\text { Total Modal }}
$$

Profitabilitas. Profitabilitas adalah kemampuan perusahaan untuk menghasilkan keuntungan dan mengukur tingkat efisiensi operasional dan efisiensi dalammenggunakan harta yang dimilikinya (Chen, 2012:268). Nidar (2016:281) mengungkapkan bahwa rasio profitabilitas atau rasio rentabilitas menunjukan keberhasilan perusahaandalam menghasilkan keuntungan. Rasio ini dapat dibagi atas empat jenis yaitu : Gross profit margin, net profit margin, return on asset, return on equity.Return on equity (ROE) merupakan tingkat pengembalian atas ekuitas pemilik 
perusahaan. Ekuitas pemilik adalah jumlah aktiva bersih perusahaan. Return on equity atau return on net worth mengukur kemampuan perusahaan memperoleh laba yang tersedia bagi pemegang saham perusahaan (Sartono, 2011). ROE secara eksplisit memperhitungkan kemampuan perusahaan dalam menghasilkan return bagi pemegang saham biasa setelah memperhitungkan bunga (biayahutang) dan biaya saham preferen (Nidar, 2016:288).

$$
\mathrm{ROE}=\frac{\text { Laba Bersih Setelah Pajak }}{\text { Total Ekuitas }}
$$

Kebijakan Deviden. Kebijakan deviden adalah mencakup keputusan mengenai apakah laba akan dibagikan kepada pemegang saham atau di tahan untuk reinvestasi dalam perusahaan. Apabila perusahaan memilih membagi laba sebagai deviden, tentunya akan mengurangi laba yang ditahan. Dampak selanjutnya akan mengurangi kemampuan sumber dana internal, demikian sebaliknya apabilaperusahaan memilih menahan laba, maka akan memperkuat atau memperbesar sumber dana internal. Dengan demikian kebijakan deviden akan berkaitan dengan struktur modal dan nilai perusahaan, Kamaludin dan Indriani, (2012:332).

Salah satu teori yang mendukung peneliti untuk menentukan perhitungan kebijakan deviden yaitu dividend payout ratio (DPR), yang berdasarkan Teori Dividen yang Relevan (The Bird in the Hand) dari Gordon dan Lintner.Teori ini menyatakan bahwa biaya modal sendiri perusahaan akan naik jika presentase laba yang dibayarkan kepada pemegang saham dalam bentuk uang tunai atau DPR (Dividen Payout Ratio) rendah, karena investor lebih suka menerima dividen dari pada Pe rolehan modal (Capital gains). Investor memandang keuntungan dividen (dividend yield) lebih pasti dari pada keuntungan capital gains (capital gains yield). Perlu diingat bahwa dilihat dari sisi investor, biaya modal s endiri dari laba ditahan adalah tingkat keuntungan yang disyaratkan investor pada saham. Laba ditahan adalah keuntungan dari dividen ( dividend yield ) ditambah keuntungan dari capital gains ( capital gains yield).

Menurut Tatang Ary Gumanti (2013:22) menjelaskan bahwa mengukur dividen yang dibayarakan oleh perusahan dapat diukur menggunakan salah satu dari ukuran umum dikenal. Dividend payout, rasio pembayaran dividen diukur dengan cara 
membagi besarnya dividen per lembar saham dengan laba bersih per lembar saham, yang secara matematis dapat dinyatakan dengan rumus berikut:

$$
\text { Dividend Payout Ratio }=\frac{\text { Deviden Per Share }}{\text { Earnings Per Share }}
$$

\section{Paradigma Penelitian dan Perumusan Hipotesis}

Berdasarkan uraian di atas, maka inti dari penelitian ini adalah bagaimana pengaruhkeputusan pendanaan, profitabilitas dan kebijakan deviden terhadap nilai perusahaan. Hal ini didukung dengan penelitian terdahulu yang menyatakan bahwa keputusan pendanaan, profitabilitas dan kebijakan deviden berpengaruh signifikan terhadap nilai perusahaan. Maka peneliti dapat merumuskan hipotesis penelitian:

$\mathbf{H}_{1}$ : DER berpengaruh signifikan terhadap return saham emiten sektor industri barang konsumsi di Bursa Efek Indonesia periode 2012-2016,

$\mathbf{H}_{2}$ : $R O E$ berpengaruh signifikan terhadap return saham emiten sektor industri barang konsumsi di Bursa Efek Indonesia periode 2012-2016,

$\mathbf{H}_{3}$ : $D P R$ berpengaruh signifikan terhadap return saham emiten sektor industri barang konsumsi di Bursa Efek Indonesia periode 2012-2016,

$\mathbf{H}_{4}$ : $D E R, R O E$ dan $D P R$ secara bersama-sama berpengaruh signifikan terhadap nilai perusahaan emiten sektor industri barang konsumsi di Bursa Efek Indonesia periode 2012-2016.

Hubungan akan hal ini digambarkan dalam paradigma penelitian berikut ini:

Gambar 3

Gambar Paradigma Penelitian

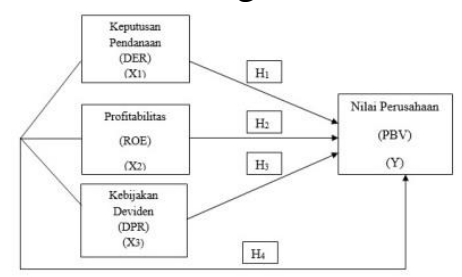

Keterangan :

PBV : Variabel dependen, Nilai Perusahaan

ROA : Variabel independen, Profitabilitas

DER : Variabel Independen, Keputusan Pendanaan

DPR : Variabel Independen, Kebijakan Deviden

$\longrightarrow \quad$ : Pengaruh Variabel Independen Terhadap Vaiabel Dependen 


\section{METODE PENELITIAN}

\subsection{Desain Penelitian}

Objek penelitian ini adalah nilai perusahaan. Subjek penelitian ini adalah perusahaan-perusahaan yang berada di dalam sektor industri barang konsumsiyang terdaftar di Bursa Efek Indonesia (BEI). Tipe penelitian ini adalah kausalitas. Menurut Sanusi (2011:14) menyatakan desain penelitian kausalitas adalah desain penelitian yang disusun untuk meneliti kemungkinan adanya hubungan sebab akibat antar variabel. Dalam desain ini umumnya hubungan sebab akibat (tersebut) sudah dapat di prediksi oleh peneliti, sehingga peneliti dapat menyatakan klasifikasi variabel penyebab, variabel antara, dan variabel terikat (tergantung). Penelitian ini bertujuan untuk menguji pengaruh variabel independen, yaitu keputusan pendanaan, profitabilitas dan kebijakan deviden terhadap variabel dependen, yaitu nilai perusahaan.

Penelitian ini menggunakan data panel. Data panel adalah gabungan antara data runtut waktu (time series) dan data silang (cross section)(Basuki dan Prawoto, 2016:275). Metode analisis data yang digunakan dalam penelitian ini adalah metode kuantitatif. Metode analisis data penelitian ini menggunakan analisis regresi linear data panel dengan teknik pengolahan data menggunakan analisis statistik deskriptif yakni menganalisa dengan berbagai dasar statistik dengan cara membaca tabel, grafik atau angka yang telah tersedia kemudian dilakukan beberapa uraian atau penafsiran dari data-data tersebut (Sujarweni, 2015: 45).

Teknik pengumpulan data pada penelitian ini adalah metode dokumentasi atau juga metode arsip yang berkaitan dengan data-data yang digunakan dalam penelitian ini, data-data yang dibutuhkan terdiri dari data sekunder. Data dalam penelitian ini diperoleh dengan mengumpulkan data empiris berupa sumber data yang dibuat oleh perusahaan berupa laporan tahunan (annual report) yang diperoleh berasal dari situs web resmi Bursa Efek Indonesia yang termuat dalam www.idx.co.id serta pencarian fasilitas jurnal online dari situs web Google Scholar www.scholar.google.co.id.

\subsection{Populasi dan Sampel Penelitian}

Populasi dari penelitian ini adalah perusahaan-perusahaan sektor industri barang konsumsi yang terdaftar di BEI periode 2012-2016 yang berjumlah 43 emiten. Menurut Sugiyono (2016:85) menyatakan bahwa: "purposive sampling adalah teknik pengambilan sampel sumber data dengan pertimbangan tertentu." Alasan menggunakan 
teknik Purposive Sampling adalah karena tidak semua sampel memiliki kriteria yang sesuai dengan fenomena yang diteliti. Oleh karena itu, penulis memilih teknik Purposive Sampling yang menetapkan pertimbangan-pertimbangan atau kriteria-kriteria tertentu yang harus dipenuhi oleh sampel-sampel yang digunakan dalam penelitian ini.

Sampel perusahaan yang berhasil diperoleh sebanyak 20 perusahaan dengan total data sebanyak 100 data yang memenuhi kriteria untuk dijadikan sampel. Adapun kriteria pengambilan sampel dalam penelitian ini sebagai berikut:

1. Merupakan perusahaan barang konsumsi yang terdaftar di Bursa Efek Indonesia selama periode 2012 - 2016. Jika perusahaan pada tahun tersebut mengalami delisting maka perusahaan tidak dijadikan sampel.

2. Perusahaan barang konsumsi yang menerbitkan laporan keuangan tahunan yang berakhir pada tanggal 31 Desember periode 2012 - 2016.

3. Perusahaan barang konsumsi yang tidak delisting dan memilki data lengkap sesuai dengan kebutuhan penulis selama periode 2012 - 2016.

\subsection{Metode Analisis}

Teknik analisis yang digunakan dalam penelitian ini adalah Metode Estimasi Data Panel Comment Effect, Random Effect danFixed Effect. Hal pertama yang dilakukan adalah menentukan model/metode estimasi regresi data panel yang tepat dalam penelitian ini, antara common effect, fixed effect, atau random effect, menggunakan uji Chowdan uji Hausman. Kemudian dilanjutkan uji asumsi klasik yang terdiri dari Normalitas menggunakan uji Jarque Bera, Multikolinearitas menggunakan uji Matriks Korelasi, Autokorelasi menggunakan uji Durbin Watson dan Heteroskedastisitas menggunakan uji Glejser, dan Lalu dilanjutkan dengan Uji Signifikansi dengan Uji Koefisien Determinasi, Uji F dan Uji T. Setelah itu adalah interpretasi.

\section{HASIL PENELITIAN DAN BAHASAN}

\subsection{Hasil Analisis Data}

Pemilihan Model Estimasi Regresi.Dengan nilaiprob. cross-section Chisquare adalah 0,0000 dengan kata lain di bawah 0,05 pada hasil uji hausman, menunjukkan bahwa fixed effect model lebih baik digunakan daripada random effect model. Kemudian dengan nilai prob adalah 0,0000 (kurang dari 0,05) pada hasil uji 
Hausman, menunjukkan bahwa metode yang lebih tepat digunakan dalam analisis data panel pada penelitian ini adalah fixed effect model. Berdasarkan hasil uji tersebut peneliti menggunakanfixed effect modelsebagai model estimasi regresi data panel dalam penelitian ini.

Uji Asumsi Klasik.Berikut adalah hasil uji asumsi klasik pada penelitian ini:

Tabel 1 Hasil Uji Asumsi Klasik

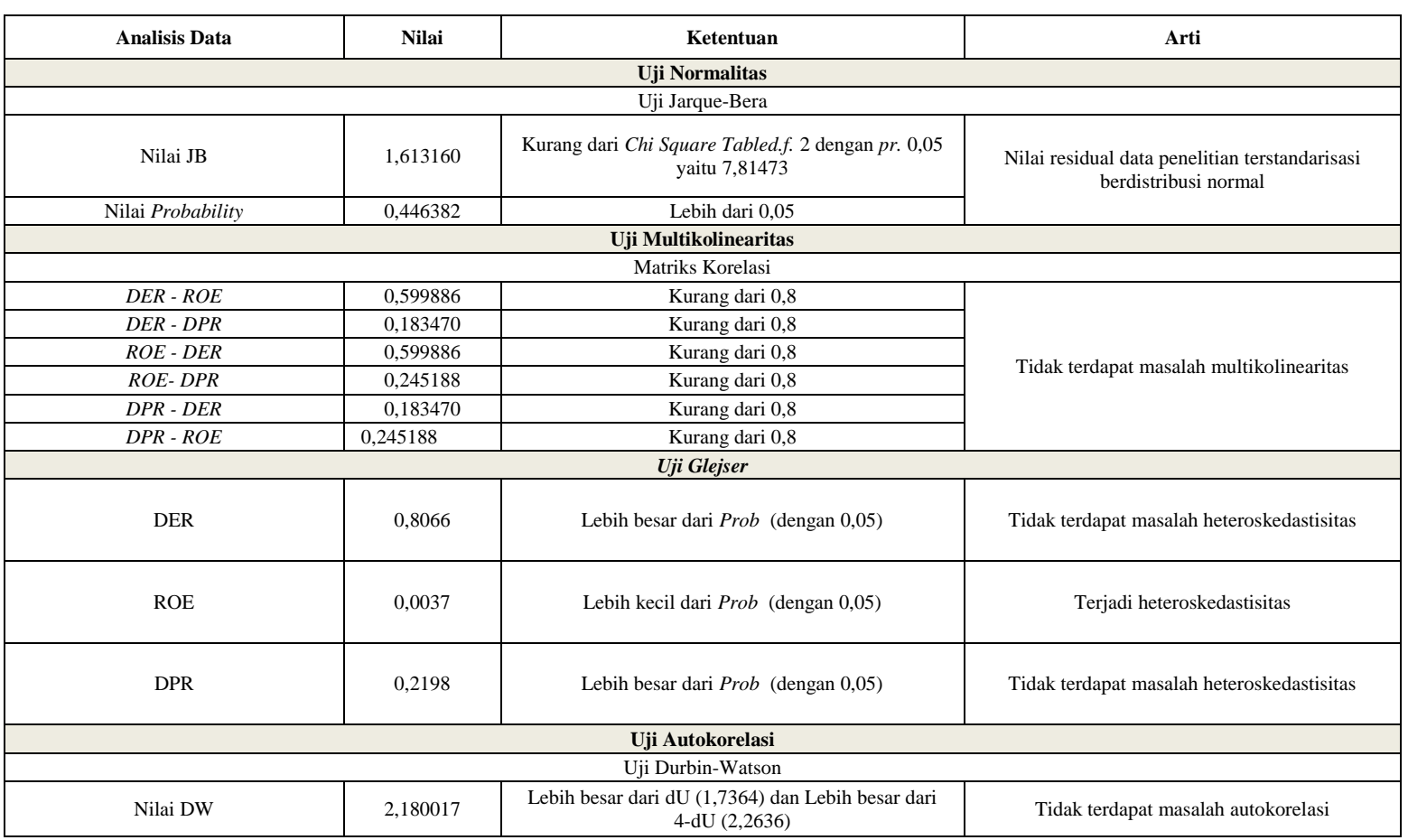

Sumber: Data Hasil Olahan Eviews 10

Persamaan Regresi. Berikut adalah hasil estimasi regresi dengan menggunakan Fixed Effect Model pada data yang diteliti setelah dilakukan uji asumsi klasik:

Tabel 2 Hasil Regresi Linear dengan Fixed Effect Model Menggunakan Eviews 10

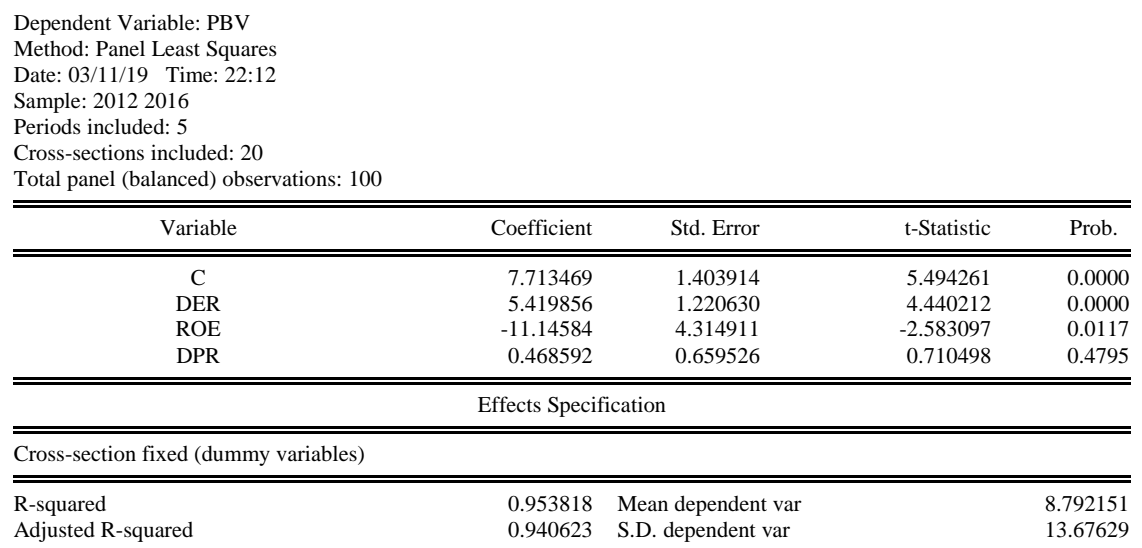




\begin{tabular}{lrlr} 
S.E. of regression & 3.332559 & Akaike info criterion & 5.443993 \\
Sum squared resid & 855.1579 & Schwarz criterion & 6.043182 \\
Log likelihood & -249.1997 & Hannan-Quinn criter. & 5.686496 \\
F-statistic & 72.28681 & Durbin-Watson stat & 2.180017 \\
Prob(F-statistic) & 0.000000 & & \\
\hline \hline
\end{tabular}

Sumber: Data yang diolah dengan Eviews versi 10

Berdasarkan hasil di atas, maka persamaan regresi sektor industri barang konsumsi selama tahun 2012-2016 adalah sebagai berikut:

$\mathrm{PBV}=$ 7,713469 + 5,419856DER $-11,14584 \mathrm{ROE}+$ 0,468592DPR + e...

Nilai constant sebesar 7,713469 menunjukkan bahwa apabila $D E R, R O E$ dan $D P R$ sama dengan nol, maka nilai perusahaan bernilai positif. Nilai perusahaanbernilai positif artinya nilai perusahaan akan tetap bernilai positif sebesar 7,713469 satuan meskipun nilai $D E R, R O E$ dan $D P R$ adalah 0 (nol).

Hasil Uji Hipotesis. Berikut adalah hasil uji hipotesis dalam penelitian ini, yang terdiri dari uji t, uji F, dan Koefisien Determinasi.

Tabel 3 Hasil Uji Hipotesis

\begin{tabular}{|c|c|c|c|}
\hline Uji t (Uji Signifikansi Individual) & t-Statistic & Nilai prob. & Hasil \\
\hline $\begin{array}{l}\text { DER berpengaruh signifikan terhadap nilai perusahaan emiten sektor } \\
\text { industri barang konsumsi di Bursa Efek Indonesia periode 2012-2016 }\end{array}$ & 4,440212 & 0,0000 & Diterima \\
\hline $\begin{array}{l}\text { ROE berpengaruh signifikan terhadap nilai perusahaan emiten sektor } \\
\text { industri barang konsumsi di Bursa Efek Indonesia periode 2012-2016 }\end{array}$ & $-2,583097$ & 0,0117 & Diterima \\
\hline $\begin{array}{l}D P R \text { tidak berpengaruh signifikan terhadap nilai perusahaan emiten } \\
\text { sektor industri barang konsumsi di Bursa Efek Indonesia periode } \\
2012-2016\end{array}$ & 0,710498 & 0,4795 & Ditolak \\
\hline Uji F (Uji Signifikansi Simultan) & F-Statistic & Nilai prob. & Hasil \\
\hline $\begin{array}{l}D E R, R O E \text { dan } D P R \text { secara bersama-sama berpengaruh signifikan } \\
\text { terhadap nilai perusahaan emiten sektor industri barang konsumsi di } \\
\text { Bursa Efek Indonesia periode 2012-2016 }\end{array}$ & 72,28681 & 0,00000 & Diterima \\
\hline Uji Koefisien Determinasi & $\begin{array}{c}\text { Adj. } R \text {-Squared } \\
\left(R^{2}\right)\end{array}$ & \multicolumn{2}{|c|}{ Hasil } \\
\hline Kemampuan model dalam menerangkan variasi variabel dependen & 0,940623 & \multicolumn{2}{|c|}{$\begin{array}{l}\text { Kemampuan dari seluruh variabel independen pada } \\
\text { penelitian ini ( } D E R, R O E \text { dan } D P R \text { ) dalam } \\
\text { menjelaskan variasi dari variabel dependen (return } \\
\text { saham) adalah sebesar } 94 \% \text {, sedangkan sisanya } 6 \% \\
\text { dijelaskan oleh variabel independen lainnya yang tidak } \\
\text { dimasukkan ke dalam model penelitian ini }\end{array}$} \\
\hline
\end{tabular}

Sumber: Data Hasil Olahan Eviews 10

\section{INTERPRETASI DATA}

\subsection{Pengaruh Keputusan Pendanaanterhadap Nilai Perusahaan}

Hasil penelitian ini menunjukkan bahwa keputusan pendanaan (Debt Equity Ratio) berpengaruh positif dan signifikan terhadap nilai perusahaan, di tunjukkan bahwa hasil probability DER 0.000 lebih kecil dari 0.05 , sehingga keputusan pendanaan yang di ambil oleh perusahaan akan sangat berpengaruh terhadap nilai perusahaan di masa sekarang atau pun yang akan datang, karena hutang dapat mengendalikan manajer untuk 
mengurangi tindakan perquisites dan kinerja perusahaan menjadi lebih efisien sehingga penilaian investor terhadap perusahaan akan meningkat.

Hasil ini konsisten terhadap penelitian Arieska dan Gunawan (2011), dimana keputusan untuk memperoleh pinjaman jangka panjang dapat menaikkan nilai perusahaan di karenakan likuiditas perusahaan akan semakin bertambah dan perusahaan akan dapat menginvestasikan kembali dana tersebut untuk meningkatkan nilai perusahaan dengan cara membuat produk baru atau meningkatkan kapasitas produksi.

\subsection{Pengaruh Profitabilitas terhadap Nilai Perusahaan}

Hasil penelitian ini menunjukkan hasil ROE berpengaruh negatif dan signifikan terhadap PBV, di tunjukkan bahwa hasil probability DER 0.0117 lebih kecil dari 0.05, dimana nilai ROE yang negatif dapat menaikkan nilai perusahaan, dikarenakan perusahaan yang menghasilkan profitabilitas yang kecil atau negatif dapat menaikkan nilai perusahaan dimana kemungkinan di masa yang akan datang perusahaan akan dapat menaikkan profitabilitas dengan mengorbankan profit di tahun berjalan untuk melakukan investasi di masa yang akan datang, sehingga investor lebih melihat kegiatan investasi perusahaan di masa yang akan datang di bandingkan melihat hasil profitabilitas di tahun berjalan, atau profit perusahaan di gunakan untuk membayar hutang sehingga investor kemungkinan melihat dari nilai hutang perusahaan yang lebih kecil di bandingkan tahun sebelumnya jika di bandingkan melihat profitabilitas yang negatif. Hasil ini konsisten dengan penelitian yang dilakukan oleh Agustine dan Darminto (2012) hasil analisis linier berganda didapatkan ROE memiliki koefisien regresi yang menunjukkan nilai negatif.

\subsection{Pengaruh Kebijakan Devidenterhadap Nilai Perusahaan}

Hasil penelitian ini menunjukkan hasil DPR tidak berpengaruh signifikan terhadap PBV, ini di tunjukkan bahwa hasil probability DPR 0.4795 lebih besar dari 0.05, sehingga kebijakan deviden yang tinggi tidak akan berpengaruh terhadap nilai perusahaan. Di karenakan tidak semua investor melihat dari jumlah dividen yang di bagikan, di karenakan banyaknya investor yang bermain di pasar modal memilih untuk berinvestasi dengan cara cepat (trader), dimana lebih melihat dari pergerakan harga saham yang fluktuatif yang di dorong oleh faktor eksternal dari perusahaan. Sehingga pembagian deviden yang besar tidak membuat nilai perusahaan akan meningkat. Hasil ini konsisten dengan penelitian yang dilakukan Eva Eko Hidayati (2011) mendapatkan 
bahwa kebijakan deviden berpengaruh negatif dan tidak signifikan terhadap nilai perusahaan.

\subsection{Pengaruh Keputusan Pendanaan, Profitabilitas dan Kebijakan Deviden Secara Simultan terhadap Nilai Perusahaan}

Dari hasil penelitian ini, dapat disimpulkan dari uji $\mathrm{F}$ (simultan) menunjukkan bahwa nilai probabilitas lebih kecil dari signifikansi 0,05 . Hal ini memiliki arti bahwa pada tingkat $\alpha=0,05$ antara Keputusan Pendanaan, Profitabilitas, dan Kebijakan Deviden secara bersama-sama (simultan) berpengaruh terhadap Nilai Perusahaan.

\section{SIMPULAN DAN SARAN}

\subsection{Simpulan}

Berdasarkan penelitian yang telah dilakukan dan dijelaskan pada bab-bab sebelumnya, maka dapat diambil kesimpulan sebagai berikut:

1. Keputusan Pendanaan berpengaruh positif dan signifikan terhadap Nilai Perusahaan, dikarenakan DER adalah rasio keuangan yang membandingkan total liabilitas dengan ekuitas. Rasio ini merupakan ukuran yang dipakai dalam menganalisis laporan keuangan untuk memperlihatkan besarnya jaminan yang tersedia untuk kreditor.

2. Profitabilitas berpengaruh negatif dan signifikan terhadap Nilai Perusahaan, dikarenakan jika peningkatan ROE akan menurunkan nilai PBV. Jadi perusahaan dengan tingkat profitabilitas tinggi akan menggunakan laba ditahan untuk membiayai kebutuhan pendanaannya. Perusahaan dengan profit tinggi, menggunakan hutang lebih sedikit. Sehingga rasio hutang relatif kecil.

3. Kebijakan Deviden tidak berpengaruh terhadap Nilai Perusahaan, dikarenakan pembagian dividen yang besar belum tentu menarik para investor, saat ini investor lebih memilih untuk memanfaatkan kenaikan yang cepat dari nilai perusahaan di karenakan faktor eksternal perusahaan.

4. Variabel Keputusan Pendanaan, Profitabilitas, dan Kebijakan Deviden secara simultan berpengaruh terhadap Nilai Perusahaan. Dengan demikian dapat diasumsikan jika nilai Rasio DER, ROE, dan DPR secara simultan berpengaruh terhadap PBV. 


\subsection{Saran}

Adapun saran yang dapat diberikan guna perbaikan penelitian ini di kemudian hari terbagi menjadi saran operasional dan saran pengembangan ilmu adalah:

1. Operasional

Untuk Perusahaan,

Agar perusahaan dapat memilih untuk menginvestasikan dananya ke sektor yang tepat, karena semakin tinggi Keputusan Pendanaan maka akan semakin menaikkan Nilai Perusahaan. Dan juga tidak semua nilai profitabilitas yang negatif dianggap oleh investor menjadi penghalang untuk investasi di perusahaan, kemungkinan investor melihat hal lain yang menarik untuk menginvestasikan dana mereka di perusahaan. Kebijakan Deviden yang besar belum tentu dapat menaikkan Nilai Perusahaan, oleh kerena itu lebih baik perusahaan menginvestasikan dananya ke sektor lain dibandingkan memberi deviden yang besar ke para investor.

2. Pengembangan Ilmu

Untuk penelitian selanjutnya direkomendasikan agar dapat mengembangkan laporan keuangan yang lebih lengkap dan periode yang lebih panjang, dan menambahkan lebih banyak variabel dependennya dan juga melakukan penelitian lebih luas lagi di lihat dari faktor eksternal yang mendukung penelitaian yang di teliti dan juga agar penelitian ini juga berguna untuk para peneliti yang ingin melakukan investasi di pasar saham sehingga dapat menjadikan tolak ukur apakah penelitian ini sesuai dengan kejadian yang ada di pasar saham sehingga dapat menjadi pembelajaran bagi pihak pengajar apakah teori ini sesuai dengan kenyataan yang ada di lapangan.

\section{DAFTAR PUSTAKA}

Afzal, Arie dan Rohman, Abdul. 2012. Pengaruh Keputusan Investasi, Keputusan

Pendanaan, dan Kebijakan Deviden terhadap Nilai Perusahaan. Jurnal Akuntansi. Universitasi Diponegoro. Vol.1 No.2.

Agustine, Rizky dan Darminto 2012. Pengaruh Return On Equity (ROE), Earning Per Share (EPS), dan Debt Equity Ratio (DER) Terhadap Harga Saham.

Babu dan Jain, 2012. Pengaruh Struktur Modal terhadap Nilai Perusahaan pada perusahaan Manufaktur. Jurnal manajemen. Vol. 2(1), 39-43. 
Basuki, Agus Tri and Prawoto, Nano. 2016. Analisis Regresi Dalam Penelitian Ekonomi \& Bisnis : Dilengkapi Aplikasi SPSS \& EVIEWS. Depok : PT Rajagrafindo Persada.

Bursa Efek Indonesia. Data Laporan Keuangan Perusahaan dan Laporan Tahunan perusahaan tahun 2012 sampai dengan 2016. Www.Idx.co.id.

Chen $\mathrm{Li} \mathrm{Ju}$ dan Chen Shin $\mathrm{Yu}$. 2012.The factors affect the value of the company. African Journal of Business Management, Vol. 5 No.27.

Gitman, Lawrence J. dan Chad J. Zutter. 2012. Principles of Managerial Finance, $13^{\text {th }}$ Edition. Global Edition: Pearson Education Limited.

Google Cendekia. Jurnal-jurnal Ilmiah. Www.scholar.google.co.id.

Hastuti dan Rachbini, 2014. Faktor-Faktor Yang Mempengaruhi Nilai Perusahaan pada perusahaa Manufaktur. Jurnal Ilmiah Mahasiswa. Universitas Mercu Buana Yogyakarta, Vol. 4(1), 39-44.

Nidar, Sulaeman Rahman. 2016. Manajemen Keuangan Perusahaan Modern, Bandung: Pustaka Reka Cipta.

Pramastuti, suluh. 2012 Analis Kebijakan Dividen : Pengujian Dividen, Signaling Theory dan Rent Extraction Hypothesis. Jurnal Ilmiah Mahasiswa. Pasca Sarjana Jurusan Magister Sains ilmu-ilmu Manajemen Universitas Gajah Mada Yogyakarta. Vol 2 dan No 4.

Sanusi, Anwar. 2011. Metode Penelitian Bisnis.Jakarta: Salemba Empat.

Sartono. 2011. Akuntansi Manajemen. Edisi kedua, Jakarta: Salemba Empat.

Sugihen, 2012, Faktor-faktor yang mempengaruhi Nilai perusahaan sektor pertambangan di bursa efek Indonesia tahun 2007-2011. Jurnal Akuntansi. Universitas Gajah Mada. Vol. 5.

Sugiyono. 2016. Metode Penelitian Pendidikan(Pendekatan Kuantitatif, Kualitatif, Dan $R \& D)$. Bandung : CV Alfabeta.

Sujarweni, V.Wiratna. 2015. Statistic. Yogyakarta:Graha Ilmu.

Www.Ticmi.co.id. Perhitungan Laporan Keuangan.

Www.Tradingeconomic.com. Portal tentang berita pergerakan ekonomi di Indonesia. 